\title{
Away from 'Unified Nostalgia’: Conceptual Differences of Personal and Historical Nostalgia Appeals in Advertising
}

Chris Marchegiani, Ian Phau

\begin{abstract}
Studies suggest that nostalgia can be split into two distinct forms; Personal and Historical nostalgia. This research explores these varieties of nostalgic appeal and, based on literature, proposes differing effects these variations may have on the important consumer behaviour responses of cognition, emotions, attitudes, and purchase intentions. A review of the literature suggests that significant differences will exist dependent on the type of nostalgic appeal being used. The call for scales to test these appeals independently of one another is also made. Finally, this evidence suggests that treatment of nostalgia as a 'unified' concept may be inaccurate in predicting true consumer responses and future studies should treat the two types as separate appeals if rigor is to be suggested.
\end{abstract}

KEYWORDS. Personal nostalgia, historical nostalgia, advertising appeals, memory process

\footnotetext{
*Christopher Marchegiani (B. Com (hons)) is currently undertaking his $\mathrm{PhD}$ at Curtin University of Technology, Perth

christopher.marchegiani@cbs.curtin.edu.au
}

Ian Phau ( $\quad$ ) is a associate professor at Curtin University of Technology, Perth Ian.Phau@cbs.curtin.edu.au 


\section{INTRODUCTION}

\section{Nostalgia: A Brief History and Background}

Nostalgia is commonly described as "a preference (general liking, positive attitude, or favourable affect) toward objects (people, places, or things) that were more common (popular, fashionable, or widely circulated) when one was younger (in early adulthood, in adolescence, in childhood, or even before birth)" (pp. 330 Holbrook and Schindler, 1991). It may affect any person, regardless of their age, social class, gender, ethnicity, or other social groupings (Sedikides, Wildschut, and Baden, 2004). Although originally based in psychology, nostalgia has been developed through sociology and marketing into a promotional appeal identified as highly effective and persuasive (Naughton and Vlasic, 1998). From a marketing viewpoint, it has been identified as an underlying theme of many marketing and advertising strategies (Cosgrove and Sheridan, 2002; Ironson, 1999; Lundegaard, 2002; Poniewozik, 2002; White, 2002) and has been implicated in a variety of behavioural research contexts, including; self-concept, brand loyalty, brand meaning, the human senses, consumption preferences, literary criticism, collective memory, and emotions (Muehling and Sprott, 2004).

Nostalgia may be caused by a number of elements, including music, photographs, movies, special events, family members, threatening stimulus, and as a deliberate response to an uncomfortable psychological state (Greenberg, Koole and Pyszczynski, 2004; Holak and Havlena, 1992). In advertisements, advertisers may be capable of explicitly encouraging 'nostalgic reflection' using executional elements such as music, jingles and visual images (Havlena and Holak, 1991). This has been tested empirically through the content analysis of television advertisements (1031 ads appearing on network TV) by Unger, McConocha and Faier (1991) who identified six elements in advertising that have nostalgia-evoking qualities. 'Period-oriented symbols' (used 30\% of the time) and 'Period-oriented music' (28\%) were indicated as the most prevalent with the other elements being; references to past family experiences, the olden days, old brands, and patriotic references. 
Nostalgia is generally described as an emotional process (e.g. Stern, 1992; Holak and Havlena, 1998) rather than a cognitive memory process (Belk, 1990), although nostalgia has been shown to influence the type and order of respondent's thoughts (e.g. Muehling and Sprott, 2004). Thus, both theories on memory processes (i.e. thought processing and retrieval) and emotions are important theoretical underpinnings for understanding nostalgia's effects in marketing. As shown in Muehling and Sprott (2004), there is considerable support in the advertising literature for the relationship between ad-evoked emotional responses (feelings) and a consumer's (1) formation of an attitude towards the brand (see Edell and Burke, 1987; Holbrook and O'Shaughnessy, 1984; Mitchell, 1986; Ray and Batra, 1983), and / or (2) formation of an attitude towards the advertisements/expression of likeability to the advert itself (see Aaker, Stayman, and Hagerty, 1986; Batra and Ray, 1986; Machleit and Wilson, 1988; Stayman and Aaker, 1988). Thus, theories on attitudinal response, such as the dual mediation hypothesis (DMH) (MacKenzie, Lutz and Belch, 1986), are also important underpinnings for studying nostalgia. These theories and how they relate to the variations of nostalgia are further explored in due course.

\section{Personal and Historical Nostalgia: Why Are They Different?}

The concept of different types of nostalgia (often referred to as 'personal' and 'historical') is discussed by a number of academics (e.g. Baker and Kennedy, 1994; Batcho, 1995; Havlena and Holak, 1991; Hirsch, 1992; Holak and Havlena, 1992; Stern, 1992). In exploring personal and historical nostalgia separately, we look to Stern (1992) and Havlena and Holak (1991) who explain that Personal Nostalgia are responses generated from a personally remembered past ('the way $I$ was'), while Historical Nostalgia are responses generated from a time in history that the respondent did not experience directly, even a time before they were born ('the way it was'). While this distinction of nostalgic appeals is made, empirical studies do not explore these varieties independently of one another. Holbrook and Schindler's (1991) previously discussed definition of nostalgia as being from a time 'when one was younger (in early adulthood, in adolescence, in childhood, or even before birth)' is a useful example of 
the 'unified' view of nostalgia that is often used in empirical studies, with no distinction made between personal and non-personal times (i.e. 'before birth’). Although of course Holbrook and Schindler's (1991) definition is correct in explaining nostalgia as the unified concept they no doubt intended, evidence suggests that marketers may wish to be wary of testing nostalgic appeals in this way. In terms of previous work, Stern (1992) encapsulates well the two appeals in suggesting as to what types of characters, values, settings and similar (in terms of literature) are best suited to which form of nostalgia, and much of this can be applied to a marketing setting. Stern also examines some products that may be better suited under the each type of nostalgia. However, the comparable 'effects' of each type of appeal as a promotion / marketing tool has on various consumers behaviour reactions is not determined or empirically measured. Stern (1992) also identifies some specific cues for evoking the two different types. Personal nostalgia cues included; familiarity, home and hearth, lifelike incidents, ordinary people, love, nurturance, and identification. These use memory as the perceiver’s 'metal process'. Historical cues include; historical incidents, romance, role models, aspirational / idealised characters, long ago settings, and sometimes exaggerated tones. Baker and Kennedy (1994) as discuss people’s tendency to embellish a reconstructed past when faced with this form of nostalgia. The metal process in this case is more fantasy / imaginary. Although the behaviour response was in a proposed form (thus not containing empirical research of suggested effects), the types of cues suggested do align with the 'real / autobiographical' vs. 'imaginary / idealised' issue on cognition that is explored next.

As discussed, this research intends to postulate that advertisers should be exploring nostalgia as two separate appeals due to variation in consumer behaviour as a result of the appeal used. The reason why these differences are expected to occur is based in the basic premise that personal nostalgia, by definition, deals with ones own past, while historical nostalgia does not. Research suggests that this will have varying effects on consumers. Theories to support this suggestion include the studies on Memory Systems (Tulving, 1972, 1984), and the theory of Autobiographical Memory (Brewer, 1986; Neisser, 1988), which has also been liken to personal (Brewer and Pani, 1983) or episodic (Tulving, 1972, 1984) memory. Autobiographical memory clearly has implications for personal nostalgia as previous research (e.g. Muehling and Sprott, 2004) has shown that nostalgia stimulates this 
form of memory. Although it is often considered a modified form of autobiographical memory as it is often somewhat filtered of negative thoughts (through "rose-colored glasses") (Belk, 1990, 1991; Davis, 1979; Havlena and Holak, 1991; Holak and Havlena, 1992; Stern, 1992), it still makes 'personal connections' (Krugman, 1967). Nostalgic thoughts are said to be self-referencing in nature due to their connection or association with an individual's real or idealized past (Belk, 1990; Holak and Havlena, 1992), which is in line with the definition of personal nostalgia. This is of importance as there is a connection between thoughts of a selfreferencing nature and salience of the thoughts (Greenwald, 1968). This suggested relationship between salience and self referencing thoughts is portrayed graphically at figure 1. This figure is used in explaining later effects of the two types of nostalgia also. The before mentioned increase in salient thoughts can be seen in Muehling and Sprott's (2004) study on nostalgia when the most salient thoughts of consumers exposed to a nostalgia evoking print advertisement were those that made a connection (often a personal connection) to something from the past.

Historical nostalgia however, cannot share these personal connections or autobiographical traits in earnest as although some personal connections may be made, the response by definition is generated from a time in history that the respondent did not experience directly, even a time before they were born ('the way it was'). Baker and Kennedy (1994, p.171) also supported this in discussing 'simulated nostalgia' in saying that someone 'can feel nostalgic or attach a symbolic meaning to an object when, in fact, the person has never experienced the event which the object represents'. Instead, historical nostalgia deals more with the theory of Collective Memory (Halbwachs, 1950). Basically, 'collective memory’ is explained as being shared, passed on, and even constructed by the group, or modern society. This has also been discussed as a nostalgic equivalent of 'virtual reality' (Holak, Matveev, and Havlena, 2008). This supports Stern's (1992) discussion of historical nostalgia as more 'imaginary', and Ross and Conway’s (1986) finding of people as inaccurate historians of their own personal information. By gaining knowledge of a time period and its associated objects, individuals may come to feel they have an understanding of what it was like to have been a part of them (Belk, 1990). This clearly shows that differences in cognitive reactions at least should take place in respondents depending on what type of nostalgia is being drawn out. This is 
supported by Baker and Kennedy’s (1994, p. 172) proposition that 'the more direct the experience, the more vivid the memories'. These changes in cognition are expected to affect other responses in consumers such as emotions, attitudes, and intentions (MacKenzie, Lutz and Belch, 1986; Petty and Cacioppo, 1986; Vakratsas and Ambler, 1999). In fact, nostalgic appeals / reactions have been specifically implicated in altering all of these reactions in previous studies (e.g. Belk, 1990; Davis, 1979; Holak and Havlena 1998; Muehling and Sprott, 2004; Pascal, Sprott and Muehling, 2002; Sierra and McQuitty 2007; Stern, 1992). However, no comparison between the two distinct types of nostalgia that respondents may experience was undertaken. Simply stated, as the current knowledge generated about nostalgia’s use in advertising has been generally limited to testing nostalgia as a 'unified concept', or at best individual types of the appeal without comparison, marketers are unaware of many of the specific differing effects or responses (if any) they may encounter when using specific forms of nostalgic appeals in their advertising. Some of these expected differences in consumer reactions are examined and suggested as areas of future empirical research.

\section{FIGURE 1: Suggested conceptual relationship between the self-referencing} nature of thoughts and their salience under nostalgic conditions.

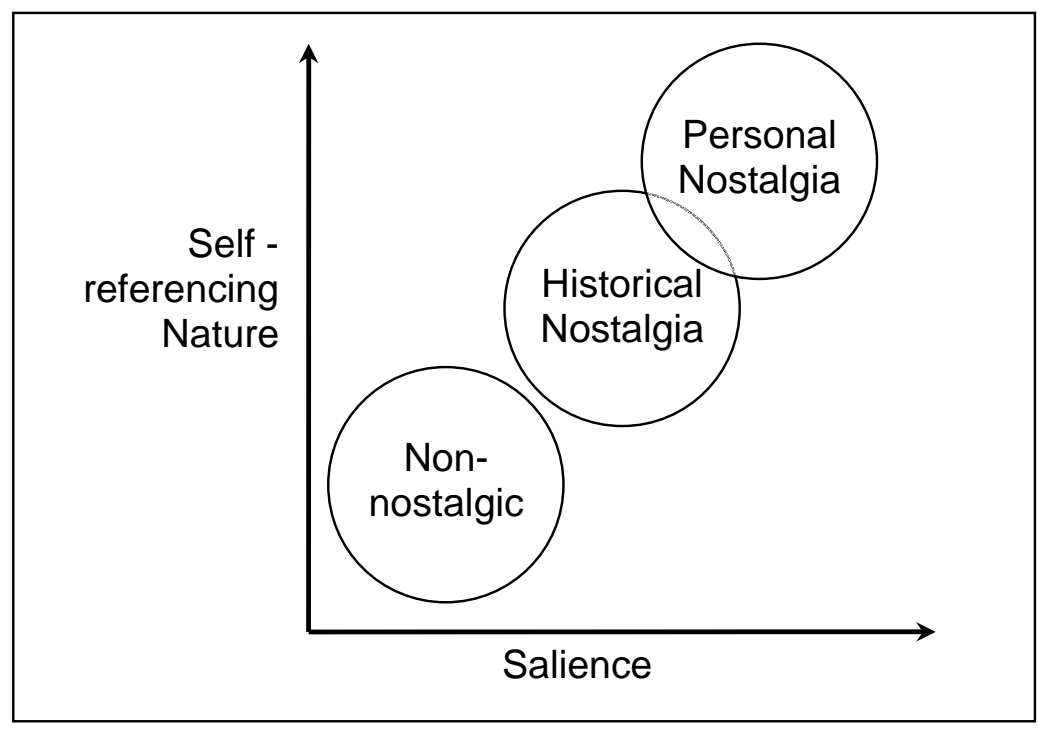




\section{SUGGESTED FUTURE RESEARCH}

\section{The Need for Scales}

If personal and historical nostalgia are to be subject to research independently or comparatively to each other, it must be clear when consumers are not only being exposed to cues of either a personal or historical nature, but also that they are actually experiencing the intended form of nostalgia. In order to do this, scales that measure each of these specific responses independently of one another is needed. Scales of this nature would also provide existence and measurement of the intensity of these specific reactions, allowing those experiencing low personal nostalgia (for example) to be compared with those experiencing high personal nostalgia, or mid levels of historical nostalgia, and so on. This would allow for a more robust understanding and better prediction of consumer behaviour reactions in consumers. This is currently a gap in the knowledge as to date no scales that measure the two forms of nostalgia independently exist. Instead, only scales that treat nostalgia as a 'unified' concept or that measure issues associated with nostalgia have been developed. For example, scales such as the 8-item 'Nostalgic proneness scale' (Holbrook, 1993) is related to both personal and historical nostalgia in the sense that it was developed as a measure of nostalgic proneness rather than nostalgic existence and has been also used in reference to 'attitude towards the past' (ATP) (Holbrook and Schindler, 1994). The 12-item 'Experience Scale' (Taylor and Konrad, 1980) has also been used to measure ATP. Likewise Baker and Kennedy's (1994) 'NostScale' is designed to establish the distinction between nostalgic feelings associated with an advertisement and positive affect for an advertisement, and Pascal, Sprott and Muehling's (2002) 10-item scale of 'evoked nostalgia' seems to contain both personal and historical related items, indicating its appropriateness for measuring nostalgia, but as with others, inability to distinguish between the two specific nostalgic reactions. These scale are all well suited and reliable for measuring their intended reaction / response, although for the purpose of dividing the nostalgic appeal, are not functional. As such, reliable, validated scales designed for measuring personal and historical nostalgia 
independently of one another is a worthwhile future research direction to pursue if we intend to better understand these advertising appeals.

\section{Effects on Cognition}

Cognition is perhaps the first important consumer behaviour reaction to occur as nostalgic cues will stimulate the retrieval / generation of thoughts by means of the consumer's memory / thought process. Memory and thought retrieval has its roots in psychology and many marketers have adapted the theories related to memory to explain the cognitive outcomes in terms of marketing. In regards to nostalgia, firstly, concerning memory, literature on memory accessibility suggests that salient thoughts should be more easily retrieved and produced in greater quantity than would less salient thoughts (Bettman, 1979; Craik and Lockhart, 1972; Wright, 1980). Research in this area also shows that salient thoughts are often selfreferencing thoughts (or "personal connections," Krugman, 1967), and they may influence mental-processing activity when attitudes are formed or retrieved (e.g. Greenwald, 1968). This finding is significant in underlying nostalgia research as per the following rational: Havlena and Holak (1991) suggest that using ad executional elements (music, jingles, visual images etc.), advertisers may be capable of explicitly encouraging ‘nostalgic reflection’ (i.e. retrieval of memories of past times). While nostalgic thoughts differ from autobiographical memories (Muehling and Sprott, 2004), as they generally provide a 'filtered' version of the past (Belk, 1990; Davis, 1979; Stern, 1992), nostalgic thoughts are by nature still selfreferencing thoughts, or 'personal connections', (Krugman, 1967) due to their connection or association with an individual's real or idealized past (Belk, 1990; Holak and Havlena, 1992). Sujan, Bettman, and Baumgartner (1993) found that advertisements that encourage retrieval of autobiographical memories evoke more thoughts about those experiences and higher levels of net positive affect than advertisements not encouraging such memory retrieval. These autobiographical memories by definition are 'self-referencing'. Coming full circle, according to studies by Muehling and Sprott (2004) the most salient thoughts of consumers exposed to nostalgic evoking print advertisements, were those that made a connection (often a personal connection) to something from the past (among those thoughts elicited by respondents 
exposed to a nostalgic ad) thus nostalgic cues that are more autobiographical should be capable of evoking a more salient group of responses. As discussed previously, historical nostalgic appeals by definition will not achieve the same level of autobiographical memory as it relies more on imagined or 'collective' memory processes. Therefore, through the original concept of memory retrieval and accessibility, a consumer subjected to a nostalgic cue laden advertisement should experience the following; that nostalgic thoughts should be more easily retrieved and produced at a greater proportion to total thoughts more so under the personal nostalgia conditions than historical due to the autobiographical nature of the appeal. This is a question that is currently unanswered empirically.

In regards to the total number of thoughts when exposed to either a nostalgic or a nonnostalgic print advert, Muehling and Sprott (2004) found participants produced approximately the same number of thoughts. This suggests hat nostalgic ads may prompt a certain type of thought production, as opposed to simply prompting more thoughts in general to be produced, which is contrary to the original hypothesis and literature that proclaims salient thoughts should be produced in greater quantity than less salient thoughts (Bettman, 1979; Craik and Lockhart, 1972; Wright, 1980). However, this study tested nostalgia as a uniform concept, not taking into account the existence of personal and historical nostalgia. Personal nostalgia may have increased salient thoughts, and as such, more thoughts produced than consumers exposed to historical nostalgic advertising appeals.

Literature shows that nostalgic thoughts are generally positive (often filtering out thoughts that are unpleasant) (Belk, 1990; Davis, 1979; Stern, 1992). Muehling and Sprott (2004) found that a more positively valanced set of nostalgic thoughts were produced when exposing their sample to nostalgic (as compared to non-nostalgic) print advertisements, but again, this did not test the comparison in personal and historical nostalgia. The tendency of respondents to filter negative thoughts when reflecting on their own life should also result in this positive valance occurring when comparing personal and historical nostalgia reactions.

Finally, Sujan, Bettman, and Baumgartner (1993) and Williams and Faber (1999) caution that using advertisements that encouraging the retrieval of autobiographical memories may act as a distraction, thus evoking fewer thoughts about the advertised product's features than 
advertisements not encouraging such form of memory retrieval. As such, advertisers may inadvertently cause product-related thoughts to be less accessible. The concept of the number of brand-/message-related thoughts when exposed to nostalgic adverts was again empirically tested by Muehling and Sprott (2004) where they found that the number of brand-/ messagerelated (product) thoughts generated during ad exposure is not significantly different between treatment groups. Although this is regarding simply the number of brand-/message-related (product) thoughts, as opposed to the feature recall and brand evaluation tested by Sujan, Bettman and Baumgartner (1993) which found when autobiographical memories (self referencing, and similar to nostalgic thoughts) were encouraged it resulted in reduced analysis of, and memory for, product information in consumers. As such this area requires further attention taking into account the two specific forms of nostalgia. The possibility of other types of thoughts (for example, brand execution) lessening as a result of increased autobiographical memory between personal and historical nostalgia could also be explored.

It should also be noted that previous studies (see Muehling and Sprott, 2004) have hypothesised nostalgia's affect as eliciting a greater number of nostalgic thoughts, as well as a greater proportion of nostalgic thoughts to total thoughts, as one hypothesis. Future research may separate these two issues, as although consumers may have a 'greater number of nostalgic thoughts' when exposed to the advertisement, they may not have greater proportion of nostalgic thoughts to total thoughts. The significance, if any, of this between personal and historical nostalgia could be tested.

The key focus of this research is to indicate some of the major gaps in the literature on the uses / implications of personal and historical nostalgia. As discussed, many previous studies look at nostalgia as a unified concept, although there have been clear indications that personal and historical evoked nostalgia may produce different results. Thus from this, the first set of future research propositions is formed:

P1: Compared to adverts containing cues evoking historical nostalgic appeals consumers exposed to advert cues leading to personal nostalgia are expected to experience at the time of ad exposure 
a) a greater number of nostalgic thoughts

b) a greater number of nostalgic thoughts specific to the type of nostalgic advert being shown

c) a greater proportion of nostalgic thoughts specific to the type of nostalgic advert being shown to total thoughts

d) a greater number of total thoughts

e) a more positively valanced set of nostalgic thoughts

f) a more positively valanced set of total thoughts

g) fewer brand-/message-related thoughts

\section{Effects on Emotions}

The difference in 'emotional' reactions that the two nostalgic appeals may have on consumers is also significant to marketers. The emotional and cognitive effects will most likely have some relation, thus they are important for marketers to understand in order to achieve the desired end goal of altering consumer response as a result of the promotion type being used. This is especially true considering the commonly accepted connection between emotions, thoughts, attitudes and intentions. Baker and Kennedy (1994) performed an exploratory study on college students with a nostalgia-themed print ad and found that feelings of nostalgia evoked by the ad (measured by Likert-scaled items) could be separated from general positive affects toward the ad. So from this, and consecutive studies, we know that nostalgia related feelings can be identified and separated. A review of the literature shows that a variety of emotional responses, including warmth, joy, gratitude, affection, and innocence, have been attributed to being elicited by nostalgic thoughts and feelings (Holak and Havlena, 1998). Although nostalgic feelings have been identified as being generally positive, there is evidence of negative nostalgic reactions also (Muehling and Sprott, 2004). This corresponds with the research (Baker and Kennedy, 1994; Havlena and Holak, 1991; Hirsch, 1992; Holak and Havlena, 1992) which identifies nostalgia as a 'bittersweet emotion' 
of both 'pleasure and regret' and as often resulting in 'sadness and a sense of loss' (Dickinson and Erben, 2006; Holak and Havlena, 1998; Wildschut, Sedikides, Arndt, Routledge, 2006). This information is significant to marketers because consumers may begin to associate the advertised product with negative thoughts. However, if the advertisement causes a negative reaction / affect response, but offers a way to remedy the feeling in question (that is by soothing the sense of loss etc. via purchase or similar), another avenue for the use of nostalgia in advertising is revealed. In terms of cognition compared to emotions in nostalgic appeal, Pascal, Sprott and Muehling (2002) posed the question of whether or not consumers actually "think" about the idealized past when they are exposed to nostalgic ads, resulting in attitude and purchase intentions, or if this same outcome is actually a result of the evoked positive nostalgic "feelings". They also called for further investigation of this issue to provide a better understanding of how nostalgic ads are processed. Holak and Havlena (1998) also found that use of the Pleasure, Arousal, Dominance (PAD) scale, a commonly used scale for testing emotional reaction, was not as useful as a more complex discrete emotion approach, due to the intensity and richness of the discrete emotions revealed under nostalgic experiences.

As with the issues discussed under cognition, again all the research conducted explores nostalgia without considering the difference between those experiencing personal and historical nostalgia. Personal nostalgia is indicated as dealing with one’s own past, while historical does not. It would be rational to assume that due to this personal connection the emotions experienced by respondents would be distinctly different depending on the type of nostalgic appeal they are exposed to. Baker and Kennedy mirror this sentiment in their postulation that 'collective nostalgia' would be less intense than the more private emotions referred to as 'real nostalgia' and 'simulated nostalgia'. We develop our argument from their suggestion and expand on the idea as, for example, the complexity of emotions in nostalgia has already been indicated as being higher than the PAD measure can handle, in addition to the previously discussed increase salience as autobiographical nature of responses increases. Stern's (1992) description of personal as 'real' and historical as almost 'imagined' also indicates a suspected difference in emotional types and intensities. There is little doubt that emotions play a large role in advertising, especially when using an emotional appeal such as nostalgia, and as such knowledge as to the differing effect of specific nostalgic appeals 
should be explored empirically. As such a second research question based on emotions is proposed.

P2: Compared to adverts containing cues evoking historical nostalgic appeals, consumers exposed to advert cues leading to personal nostalgia are expected to experience at the time of advert exposure significant differences in the types, intensity and valance of emotions.

\section{Effects on Attitudes}

Attitudes are commonly shown to effect purchase intentions, making any change in attitudes due to the type of appeal utilised of significance to marketers. Fishbein (1963, 1967; Fishbein and Ajzen, 1975) is often hailed as presenting possibly the clearest theoretical explanation of the causal basis of attitudes at the time (Mitchell and Olson, 1981). Fishbein's work on attitude theory set out the attitude-belief relationship, which had a basic theoretical proposition that beliefs cause attitude, and as such, because attitude is determined by a set of salient beliefs, changes in attitude must be mediated by changes in those beliefs. Thus, modification of the salient beliefs about the concept is a way in which to change the person's attitude towards the concept (Fishbein and Ajzen, 1975; Mitchell and Olson, 1981). It was also proposed that the equation set out by Fishbein held for specific behaviour, such as buying a product. Although this belief has continued to be, at least in part, true, subsequent researchers have further developed on this theory to incorporate other relationships and mediating factors.

To better explain the development of the next research suggestion, it should be again recapped that the nature of nostalgia is generally positive (Holbrook and Schindler, 1991) and filtered of negative thoughts (Belk, 1990; Davis, 1979; Stern, 1992). There has been previous support (e.g. Neeb, Faier, and Unger, 1989; Pascal, Sprott, and Muehling, 2002) for the notion that nostalgic-themed ads may produce a greater preference for the advertisement as examined in individual's responses to nostalgic print ads, and it was observed that a positive relationship between ad-evoked nostalgia and attitudes toward the ad exists. Edell and Burke 
(1987) reported on how the 'feelings' of consumers have an affect on a consumer's attitude towards the advertisement (Aad), and through evidence such as the Dual Mediation Hypothesis (MacKenzie, Lutz and Belch, 1986) we can expect this to in turn affect attitude towards the brand (Ab) and purchase intentions (Ib). Other studies (Fishbein and Ajzen, 1975; Mitchell and Olson, 1981; Shrimp, 1981) also suggest that affective responses to advertising can be classified into two types leading to the formation of (a) an attitude toward the ad, and (b) an attitude toward the brand. From this rational, in addition to the knowledge discussed previously regarding the existence of both personal and historical nostalgia, we suggest that empirical evidence would show a change in attitudes dependent on the type of nostalgia being experienced. A hypothesis along these lines with nostalgia as a unified concept has been tested by Muehling and Sprott (2004), but, again, it has not been tested with taking into account the possible differing effects of personal and historical nostalgia, (this is noted as a recommendation for future research) and from this information we would suggest that:

P3: Advertisements with cues evoking personal nostalgic will produce (compared with similar advertisements evoking historical nostalgia):

(a) more favourable attitudes toward the advert

(b) more favourable attitudes toward the advertised brand

\section{Effects on Purchase Intentions}

Similar to the case on attitudes, thoughts and feelings being significantly changed as the change in nostalgic cues occurs is expected to alter intentions to purchase the brand (Ib). Nostalgia has already been implicated in effecting Ib in previous studies (Pascal, Sprott and Muehling, 2002; Schindler and Holbrook, 2003). But again, knowledge on how the two variations of nostalgia may differ in their effect on Ib is unknown. In conjunction with the previous discussion on the nature of personal and historical nostalgia it is suggested that: 
P4: Advertisements with cues evoking personal nostalgic will produce increased intention to purchase the brand compared with similar advertisements evoking historical nostalgia.

\section{Models of Nostalgia}

So far the two nostalgic appeal's possible differing effects on cognition, emotions, attitudes and intentions have been discussed. Previous studies draw connections between these commonly explored consumer behaviour reactions (MacKenzie, Lutz and Belch, 1986; Vakratsas and Ambler, 1999; Pascal, Sprott and Muehling, 2002). Opportunities to develop models incorporating these or other reactions under the two nostalgic contexts would be worthwhile. Multi-group analysis in exploring any differences in the relationships between the various types of consumer behaviour responses would be a valuable undertaking.

\section{IMPLICATIONS AND FUTURE RESEARCH SUGGESTIONS}

The significant conceptual, methodological and practical contributions of undertaking empirical studies to explore the suggested research questions this study are discussed.

Achieving the research suggestions made in this paper would greatly assist in improving our understanding of how nostalgic appeals in advertising works. The research gives reason to believe that, dependent on the specific type of nostalgia being experienced by consumers, significant changes in cognition, emotions, attitudes and intentions may occur. This is of significance to marketers as better prediction and control of these important consumer behaviour responses are of clear relevance to the advertising environment today. It is clear that any cue, especially that can be controlled by marketers, which will evoke a response that may significantly influence the thoughts, emotions, attitudes, and intentions of consumers, is one of notable practical implications. Knowledge on the effectiveness of these two promotional / marketing appeals may also indicate increased opportunities for application. As nostalgia has been implicated in such a range of consumer behaviours, the findings of such 
research may also have implications across nostalgia's use in other practical areas, such as brand loyalty.

Such studies would also make a large theoretical contribution as past research has been concerned with nostalgia as a 'unified' concept, with limited research into personal and historical nostalgia as separate conditions. This has meant that the costs and benefits between the two forms have not been empirically explored, although suggestions have been made that this should occur (e.g. Baker and Kennedy, 1994; Muehling and Sprott, 2004). Some of the clearest examples of theoretical significance of such research being undertaken would include development of scales and models that take into account the type of nostalgia being explored.

From such research, future research into the other various responses that nostalgia has been implicated in could be undertaken (for example, various respondent groups, product types and advertising mediums). This future research would benefit from the methodological contribution that research into scales and models would make.

This area is one of significant growth potential and, combined with nostalgia popular use in today’s marketplace, further knowledge and understanding would be timely and valuable.

\section{REFERENCES}

Aaker, D. S., Stayman, D. M., and Hagerty, M. R. (1986). Warmth in Advertising: Measurement, Impact, and Séquence Effects, Journal of Consumer Research, 12(4), 365381.

Baker, S. M., and Kennedy, P. F. (1994). Death by nostalgia: A diagnosis of context-specific cases, Advances in Consumer Research, 21, 169-174.

Batcho, K. I. (1995). Nostalgia: A psychological perspective, Perceptual and Motor Skills, 80, 131-143.

Batra, R., and Ray, M. L. (1983). Operationalizing Involvement as Depth and Quality of Cognitive Response, in Advances in Consumer Research, 10, Richard P. Bagozzi and Alice M. Tybout, eds., Ann Arbor: Association for Consumer Research, 309-313.

Belk, R. W. (1991). Possessions and the sense of past, Highways and Buyways, 114-130. 
Belk, R. W. (1990). The role of possessions in constructing and maintaining a sense of past, Advances in Consumer Research, 17, 669-676.

Bettman, J. R. (1979). Memory Factors in Consumer Choice: A Review, Journal of Marketing, 43(2), 37-53.

Brewer, W. F. (1986). What is autobiographical memory?, in Autobiographical memory. Rubin, D.C. Cambridge, England, Cambridge University Press: 25-49.

Brewer, W. F., and Pani, J. R. (1983). The structure of human memory, in The psychology of learning and motivation, G.H. Bower. New York, Academic Press. 17, 1-38.

Cosgrove, J, and Sheridan, P. (2002). Listen Up, Sucka, the '80s Are Back, Business Week (August 5), 16.

Craik, F. I. M., and Lockhart, R. S. (1972). Levels of Processing: A Framework for Memory Research, Journal of Verbal Learning and Verbal Behavior, 11, 671-684.

Davis, F. (1979). Yearning for yesterday: A sociology of nostalgia, New York: The Free Press.

Dickinson, H., and Erben, M. (2006) Nostalgia and Autobiography: The Past in the Present, Auto/Biography, 14(3), 223-244.

Edell, J. A., and Burke, M. C. (1987). The Power of Feelings in Understanding Advertising Effects, Journal of Consumer Research, 14(3), 421-433.

Fishbein, M. (1967). A Behavior Theory Approach to the Relations Between Beliefs About an Object and the Attitude Toward that Object, Readings in Attitude Theory and Measurement. M. Fishbein. New York, John Wiley \& Sons, Inc.

Fishbein, M. (1963). An Investigation of the Relationships between Beliefs about an Object and the Attitude Towards That Object, Human Relation, 16 (Aug). 233-240.

Fishbein, M., and Ajzen, I. (1975). Belief, Altitude, Intention and Behavior: An Introduction to Theory and Research, Reading, MA, Addison-Wesley.

Greenberg, J., Koole, S. L., and Pyszczynski, T. A. (2004). Handbook of experimental existential psychology, New York: Guilford Press. 
Greenwald, A.G. (1968). Cognitive Learning, Cognitive Response to Persuasion, and Attitude Change, in Psychological Foundations of Attitudes, Greenwald, A.G., Brock, T.C., Ostrom, T.M., eds., New York: Academic Press.

Halbwachs, M. (1950). The Collective Memory, New York, Harper Colophon Books.

Havlena, W. J., and Holak, S. L. (1991). The Good Old Days: Observations on Nostalgia and Its Role in Consumer Behavior, Advances in Consumer Research, 18, 323-329.

Hirsch, A. R. (1992). Nostalgia: A Neuropsychiatric Understanding, in Advances in Consumer Research, 19, John E Sherry, Jr., and Brian Sternthal, eds., Provo, UT: Association for Consumer Research, 390-395.

Holak, S. L., Matveev, A. V., and Havlena, W. J. (2008). Nostalgia in post-socialist Russia: Exploring applications to advertising strategy, Journal of Business Research, 61, 172178.

Holak, S. L., and Havlena, W. J. (1998). Feelings, Fantasies, and Memories: An Examination of the Emotional Components of Nostalgia, Journal of Business Research, 42(3), 217226.

Holak, S. L., and Havlena, W. J. (1992). Nostalgia: An Exploratory Study of Themes and Emotions in the Nostalgic Experiences, Advances in Consumer Research, 19, 380-387.

Holbrook, M. B. (1993). Nostalgia and consumption preferences: Some emerging patterns of consumer tastes, Journal of Consumer Research, 20, 245-256.

Holbrook, M. B., and O'Shaughnessy, J. (1984). The Role of Emotion in Advertising, Psychology and Marketing, 1(2), 45-64.

Holbrook, M. B., and Schindler, R. M. (1991). Echos of the Dear Departed Past: Some Work in Progress on Nostalgia, Advances in Consumer Research, 18, 330-333.

Holbrook, M. B. and Schindler, R. M. (1994). Age, Sex, and Attitude Toward the Past as Predictors of Consumers' Aesthetic Tastes for Cultural Products. Journal of Marketing Research, 31(3), 412-422.

Ironson, C. L. (1999). Nostalgia-Based Promotions: Past Perfect, Imprint (Summer), 48-55. 
Krugman, H. (1967). The Measurement of Advertising Involvement, Public Opinion Quarterly, 30, 583-596.

Lundegaard, K. (2002). BMW 'Mini' Campaign: Odd to the Max, The Wall Street Journal (March 1), B5.

Machleit, K. A., and Wilson, R. D. (1988). Emotional Feelings and Attitude Toward the Advertisement: The Roles of Brand Familiarity and Repetition, Journal of Advertising, 17(3), 27-35.

MacKenzie, S. B., Lutz, R. J., and Belch, G. E. (1986). The Role of Attitude Toward the Ad as a Mediator of Advertising Effectiveness: A Test of Competing Explanations, Journal of Marketing Research, 23 (2). 130-143.

Mitchell, A.A., and Olson, J.C. (1981). Are Product Beliefs the Only Mediator of Advertising Effects on Brand Attitude?, Journal of Marketing Research, 18, (August). 318-32.

Mitchell, Andrew A. (1986), "some Issues Surrounding Research on the Effects of Feeling Advertisements," in Advances in Consumer Research, vol. 13, Richard J. Lutz, ed., Provo, UT: Association for Consumer Research, 623-628. Muehling, D. D., and Sprott, D. E. (2004). The Power of Reflection: An Empirical Examination of Nostalgia Advertising Effects, Journal of Advertising, 33 (3). 25-36.

Naughton, K., Vlasic, B., and Grover, R. (1998). The Nostalgia Boom: Why the Old is New Again, Business Week, March 23, iss. 3570, 58 - 64.

Neeb, D. M., Faier, J. A., and Unger, L. S. (1989). The Effect of Nostalgic Advertising: An Experiment, in Advances in Marketing, Peter G. Gordon and Bert J. Kellerman, eds., New Orleans: Southwestern Marketing Association, 128-132.

Neisser, U. (1988). What is ordinary memory the memory of? in Remembering reconsidered: Ecological and traditional approaches to the study of memory. U. Neisser and E. Winograd. Cambridge, England, Cambridge University Press, 356-373.

Pascal, V.J., Sprott, D.E., and Muehling, D.D. (2002). The Influence of Evoked Nostalgia on Consumers' Responses to Advertising: An Exploratory Study, Journal of Current Issues and Research in Advertising, 24 (1). 39-49. 
Petty, R.E., and J.T. Cacioppo (1981). Attitudes and Persuasion: Classic and Contemporary Approaches, Dubuque, IA, W.C. Brown.

Poniewozik, James (2002), Look Back in Angst, Time (September 23), 73-71

Ray, M. and Batra, R. (1983), Emotion and Persuasion in Advertising: What We Do and Don't Know About Affect, in Advances in Consumer Research, 10, Richard P. Bagozzi and Alice M. Tybout, eds., Ann Arbor, MI: Association for Consumer Research, 543-548.

Ross, M., and Conway, M. (1986). Remembering One's Own Past: The Construction of Personal Histories, Handbook of Motivation and Cognition: Foundations of Social Behavior, eds. Richard M. Sorrentino and E. Tory Higgins, New York: The Guilford Press, 122-144.

Schindler, R. M., and Holbrook, M. B. (2003). Nostalgia for early experience as a determinant of consumer preferences, Psychology \& Marketing, 20 (4). 275-302.

Sedikides, C., Wildschut, T., and Baden, D. (2004). Nostalgia: Conceptual Issues and Existential Functions, from the Handbook of experimental existential psychology, Greenberg, J., Koole, S. L., and Pyszczynski, T. A. (eds) (2004). New York: Guilford Press.

Sierra, J. J., and McQuitty, S. (2007). Attitudes and Emotions as Determinants of Nostalgia Purchases: An Application of Social Identity Theory, Journal of Marketing Theory and Practice, 15(2), 99-112.

Stayman, D. M., and Aaker, D. A. (1988). Are All Effects of Ad-Induced Feelings Mediated by [A.sub.ad]?, Journal of Consumer Research, 15(2), 368-373.

Stern B. B. (1992). Historical and personal nostalgia in advertising text: The fin de siecle effect, Journal of Advertising, 21 (4). 11-22.

Sujan, M., Bettman, J. R., and Baumgartner, H. (1993). Influencing Consumer Judgments Using Autobiographical Memories: A Self-Referencing Perspective, Journal of Marketing Research, 30(4), 422-436.

Taylor, S. M., and Konrad, V. A. (1980). Scaling dispositions toward the past, Environment and Behavior, 12, 283-307. 
Tulving, E. (1984). How Many Memory Systems Are There?, American Psychologist, 40(4), 385-398.

Tulving, E. (1972). Episodic and semantic memory, Organisation of memory, E. Tulving and W. Donaldson. New York, Academic, 381-403.

Unger, L. S., McConocha, D. M., and Faier, J. A. (1991). The Use of Nostalgia in Television Advertising: A Content Analysis, Journalism Quarterly, 68(3), 345-353

Vakratsas, D., and Ambler, T. (1999). How advertising works: What do we really know? Journal of Marketing, 63(1), 26-43.

White, R. B. (2002), Why It's Cool to Troll Through Time, Time, 16.

Wildschut, T., Sedikides, C., Arndt, J., and Routledge, C. (2006). Nostalgia: content, triggers, functions, Journal of Personality and Social, 91(5), 975-993

Williams, JL., Faber, RJ., 1999. Everything Old is New Again: The Use of Nostalgia Appeals in Advertising. Paper accepted to the Association for Education in Journalism and Mass Communication Conventions Advertising Division - Research Session New Orleans, LA August 1999.

Wright, P. L. (1980). Message-Evoked Thoughts: Persuasion Research Using Thought Verbalizations, Journal of Consumer Research, 1(2), 151-175. 